\title{
Production of fired clay brick from municipal solid waste incinerator fly ash
}

\author{
Violeta Voišnienè ${ }^{1}$, Olga Kizinievič², Viktor Kizinievič³ ${ }^{3}$ Jurgita Malaiškiené ${ }^{4}$ \\ ${ }^{1}$ Department of Building Materials and Fire Safety, Vilnius Gediminas Technical University, Vilnius, Lithuania \\ 2, 3, ${ }^{4}$ Laboratory of Composite Materials, Institute of Building Materials, Vilnius Gediminas Technical University, \\ Linkmenu g. 28, LT-08217 Vilnius, Lithuania \\ E-mail: ${ }^{1}$ violeta.voisniene@vgtu.lt (correspondingauthor)
}

\begin{abstract}
This paper is a report on the results of a feasibility study on the immobilization of municipal solid waste incinerator fly ash by producing a fired clay brick. The main purpose of this work was to test the clay used in the manufacture of a fired clay brick that could incorporate municipal solid waste incinerator fly ash. The raw materials, municipal solid waste incinerator fly ash and clay, were mixed together in different proportions (100:0, 97.5:2.5, 95:5 and 92.5:7.5). Clay brick samples were heated to $1000^{\circ} \mathrm{C}$ temperatures for $1 \mathrm{~h}$. The fired clay brick specimens were characterised with respect to compressive strength, porosity, linear shrinkage (after drying, after firing) and density. Leaching tests, in accord with the European Union regulation, was done on fired clay brick made with different additions of municipal solid waste incinerator fly ash.
\end{abstract}

Keywords: municipal solid waste incineration, fly ash, hazardous waste, fired clay brick, plasticity index, waste recycling.

\section{Introduction}

Waste material recycling and energy saving are very important research fields today. Increased production and the development of based industries in many countries in the world have brought about the production of large quantities of municipal solid wastes, most of which are not adequately managed and utilized. Municipal solid wastes (MSW) have been used for energy production, but little work has been carried out to develop utilization of fly ash and bottom ash (slag) wastes in the production of construction materials.

During the incineration, most MSW is converted to combustion residues such as hazardous fly ash and hazardous or non-hazardous bottom ash (Van Herck, Van der Bruggen, Vogels, \& Vandecasteele, 2000; Wunsch, Greilinger, Bieniek, \& Kettrup, 1996; European Waste Catalogue [EWC], 2015).

Literature analysis revealed that the main components of MSWI fly ash are $\mathrm{CaO}, \mathrm{SiO}_{2}$ and $\mathrm{Al}_{2} \mathrm{O}_{3}$ (Wan, 2017; Ye et al., 2016; Pan, Huang, Kuo, \&, Lin, 2008). There is also a significant content of chlorides. MSWI fly ash also contains high levels of heavy metals, such as $\mathrm{Zn}, \mathrm{Pb}, \mathrm{Cu}, \mathrm{Cd}, \mathrm{Cr}$ and other (Aubert, Husson, \& Sarramone, 2006, 2007; Tang, Petranikova, Ekberg, \& Steenari, 2017; Shi \& Kan, 2009).

MSWI fly ash is reused in cement and concrete manufacture (Gao, W. Wang, Ye, F. Wang, \& Lan, 2008; Pan et al., 2013; Hwang, Bui, Lin, \& Lo, 2012; Siddique, 2010). MSWI fly ash can be also used in clay brick manufacturing (Belmonte, Ottosen, Kirkelund, Jensen, \& Vestbo, 2018; Arsenovic, Radojevic, \& Stankovic, 2015; Jordán, Montero, Rincón-Mora, Rincón, \& Sanfeliu, 2015; Arsenović, Radojević, Jakšić, \& Pezo, 2015). On the one hand, MSWI fly ash additive reduces the density and compressive strength of construction products; on the other hand, it impairs their shrinkage (drying and total) properties. However, there is still a need to relate the effect of MSWI fly ash on porosity characteristics and environmental toxicity of fired clay brick.

The main objective of this study is to investigate the effects of the municipal solid waste incinerator fly ash on the properties of fired clay bricks.

\section{Methods, materials, procedures}

The clay used in this study was a typical clay from a well known local area for making clay bricks. Chemical analyses of clay and MSWI fly ash were carried out using X-ray fluorescence technical. The chemical composition of 
clay materials is given in Figure 1a. The mineralogical composition of clay and MSWI fly ash were achieved using an X-ray diffractometer technique (XRD, Dron-7, Russian). The major crystalline phases found in clay were quartz, mico clay, kaolinite and feldspar and found in MSWI fly ash calcuim chloride, calcite, potassium calcium chloride, halite, sylvite, anhydrite. The chemical composition of clay is given in Figure 1a. The major components observed in the clay were $\mathrm{SiO}_{2}(51.43 \%), \mathrm{Al}_{2} \mathrm{O}_{3}(20.54 \%), \mathrm{Fe}_{2} \mathrm{O}_{3}(7.44 \%), \mathrm{CaO}(4.26 \%), \mathrm{MgO}(3.07 \%), \mathrm{K}_{2} \mathrm{O}(3.3 \%), \mathrm{Na}_{2} \mathrm{O}$ $(0.42 \%)$ and L.o.i. $-9.54 \%$. The chemical composition of MSWI fly ash is given in Figure 1 b. The major components observed in the MSWI fly ash were $\mathrm{CaO}(45.17 \%)$ and chloride $\left(\mathrm{KCl}, \mathrm{MgCl}_{2}, \mathrm{NaCl}\right)(19.01 \%)$. The next most components were $\mathrm{Na}_{2} \mathrm{O}(2.65 \%), \mathrm{K}_{2} \mathrm{O}(3.52 \%), \mathrm{MgO}(1.15 \%), \mathrm{Al}_{2} \mathrm{O}_{3}(1.08 \%)$. High concentrations of heavy metals were observed in the fly ash samples: As $(13.8 \mathrm{mg} / \mathrm{kg}), \mathrm{Pb}(1987 \mathrm{mg} / \mathrm{kg}), \mathrm{Cd}(83.4 \mathrm{mg} / \mathrm{kg}), \mathrm{Cr}(50.5 \mathrm{mg} / \mathrm{kg}), \mathrm{Cu}$ $(625 \mathrm{mg} / \mathrm{kg}), \mathrm{Ni}(12.2 \mathrm{mg} / \mathrm{kg}), \mathrm{Hg}(10.4 \mathrm{mg} / \mathrm{kg}), \mathrm{Zn} \quad(10209 \mathrm{mg} / \mathrm{kg}), \mathrm{Ba}(237 \mathrm{mg} / \mathrm{kg}), \mathrm{Sn}(367 \mathrm{mg} / \mathrm{kg}), \mathrm{Co}$ (5.99 mg/kg), Sr (239 mg/kg) (Figure 1b).

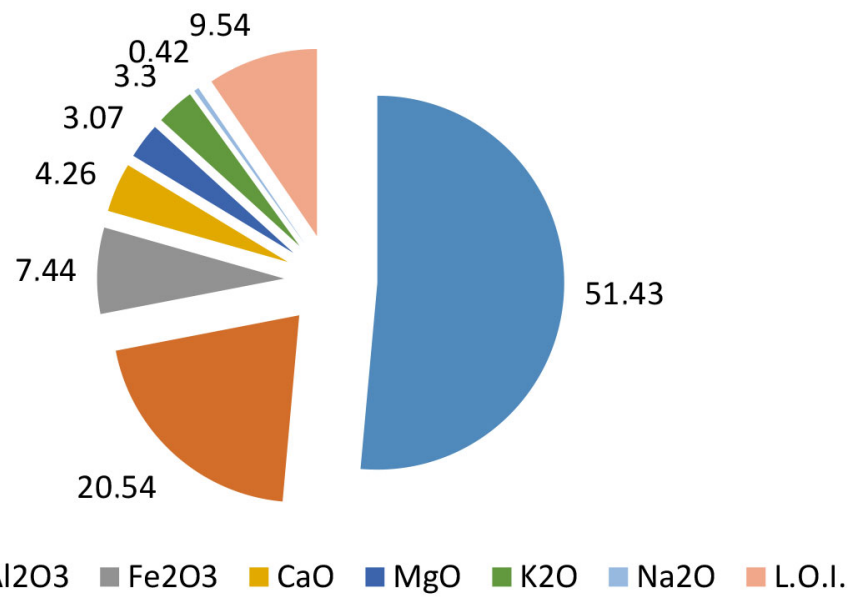

a)

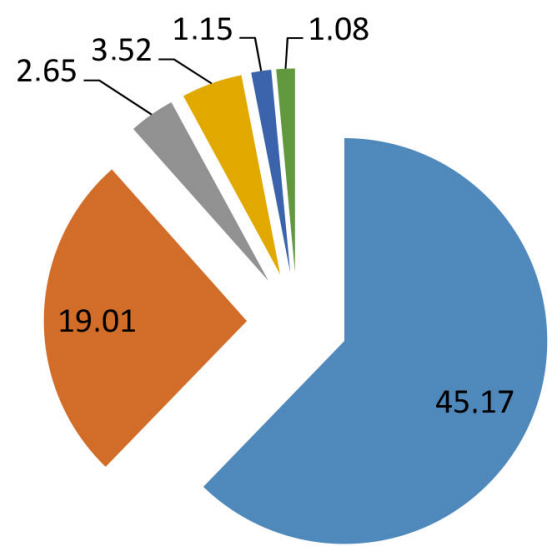

$\square \mathrm{CaO} \square$ Chloride $(\mathrm{KCl}, \mathrm{MgCl} 2, \mathrm{NaCl}) \quad \mathrm{Na} 2 \mathrm{O} \square \mathrm{K} 2 \mathrm{O} \square \mathrm{MgO} \square \mathrm{Al} 2 \mathrm{O} 3$

b)

Figure 1. Chemical composition of clay and municipal solid waste incinerator fly ash

In order to compare the clay brick (I - 0\% MSWI fly ash) and bricks made of clay and MSWI fly ash (II $2.5 \%$, III $-5.0 \%$ and IV $-7.5 \%$ fly ash), each batch of specimens was mixed in a porcelain ball mill to ensure homogenous mixing. In normal brick production, however, normal mixing would be sufficient to save time and cost. Then, $20-25 \%$ of water was added and mixed to obtain plastic condition of mixture.

Soft-mud clay bricks with dimension of $50 \times 50 \times 50 \mathrm{~mm}$ were formed using brick hand molding. The clay brick specimens were air-dried at room temperature $\left(20-25^{\circ} \mathrm{C}\right)$ for $24 \mathrm{~h}$, and then fully dried at $110 \pm 5{ }^{\circ} \mathrm{C}$ for another $48 \mathrm{~h}$ to remove water content. The green specimens were fired at temperature $1000^{\circ} \mathrm{C}$. The time taken to reach the required temperature was $10 \mathrm{~h}$ and the specimens were kept at this temperature for $1 \mathrm{~h}$. At least 6 samples were used for each test and for all categories. The averages are presented and discussed in results and discussion section. 
The compressive strengths of specimens were measured in accordance with LST EN 772-1:2011 (Lithuanian Standards Board, 2011b), density accordance with LST EN 772-13:2003 (Lithuanian Standards Board, 2003a), water absorption accordance with LST EN 771-21:2011 (Lithuanian Standards Board, 2011a). Total porosity are determined in accordance with the methodology (Sadūnas, 1999; Mačiulaitis, 1996), leaching, sulfate and chloride accordance with LST EN 12457-2:2003 (Lithuanian Standards Board, 2003b). The reported results of all tests were the average of 6 samples.

Shrinkage was determined by direct measurement of specimen length before and after firing. The linear drying shrinkage and total linear shrinkage were measured and compared to the length before shrinkage in accordance with equations (O. Kizinievič, V. Kizinievič, Pundienè, \& Molotokas, 2018).

\section{Results and discusions}

This paper reports the results of a feasibility study on the immobilization of municipal solid waste incinerator (MSWI) fly ash by transforming it into a fired clay brick product. The main purpose of this work was to test the use of clay in the formation of a fired clay body that could incorporate municipal solid waste incinerator (MSWI) fly ash.

The general criterion on the formulation of fired clay bricks is to mix a plastic component, usually a clay with a founder and a non-plastic material, that will form the basis of the final structure of the product. Municipal solid waste incinerator (MSWI) fly ash can be incorporated into the ceramic mass as the non-plastic component (Figure 2). Plasticity index refers to the resistant force to deformation and gives a better appraisal of the behaviour of plastic substance.

The plasticity indices of clay and the effect of fly ash are shown in Figure 2. The results of Atterberg tests of clay-fly ash mixtures indicate that the value of Plasticity Index decreases when fly ash content increases in the mixture. The plasticity index of clay is 18.5 , but it decreases with replacing of clay by fly ash because fly ash is a kind of lean material. When the proportion of municipal solid waste incinerator fly ash in bricks is $2.5 \%$ by mass, the plasticity indices of mixtures decreases to 17.1 , and $7.5 \%$ to 15.5 of fly ash.

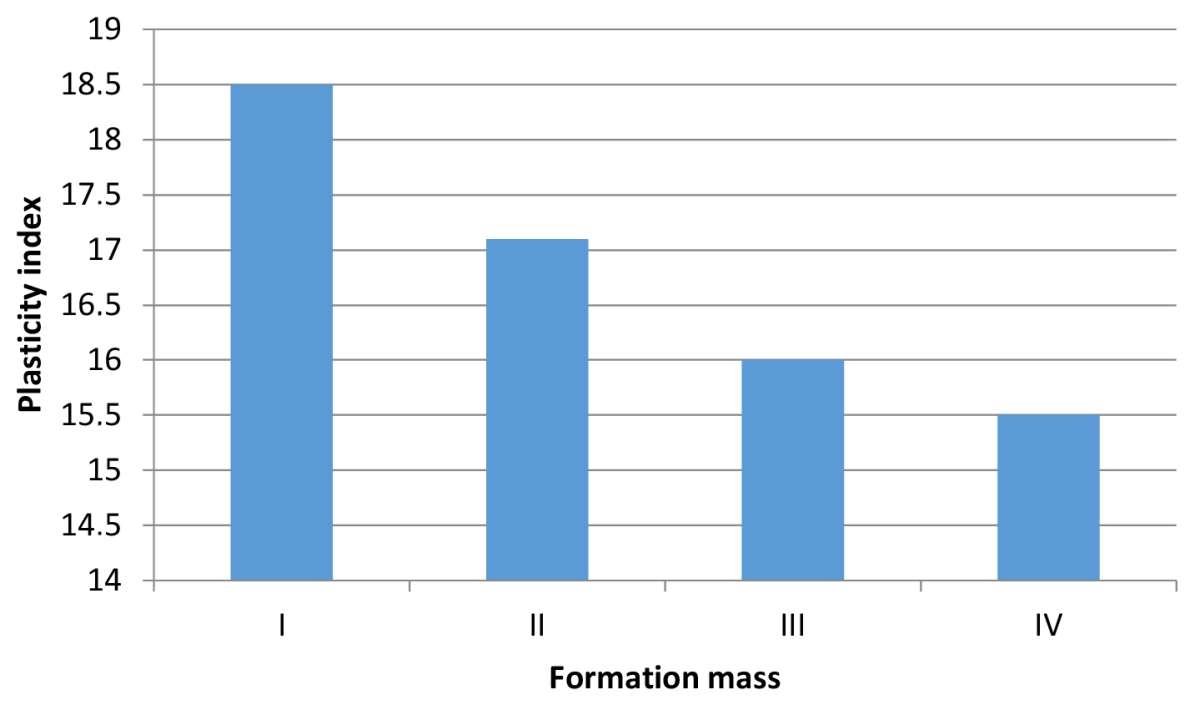

Figure 2. Plasticity indexes of clay and clay-fly ash mixtures

The density decreases with increasing of ratio of fly ash in bricks, especially when the ratio is higher than $5.0 \%$ (Figure 3). From this figure it can be seen that the total porosity increases when the percentage of fly ash in the fired clay brick is greater. The results show that for a firing temperature of $1000^{\circ} \mathrm{C}$ and for fired clay samples without any addition of fly ash the total porosity is $22 \%$.

After drying the samples, no defects were observed. Cracks, bloating, and other noticeable defects were not observed after firing. The effect of the fly ash on the total shrinkage and drying shrinkage of the clay body is summarized in Figure 4. It was observed that increasing the fly ash addition to the clay body decreases the drying shrinkage and total shrinkage of the clay-fly ash mixture and firing clay brick. The capability of fly ash to not absorb water is thought to be the main reason for the decrease in drying shrinkage and total shrinkage.

The drying shrinkage diminishes because fly ash forms a framework inside the moulded specimen. This framework prevents the moving of clay particles closer to each other during the drying. Non-plastic particles of fly ash stabilise the drying process irrespective of higher water demand in the forming phase (Figure 2). 


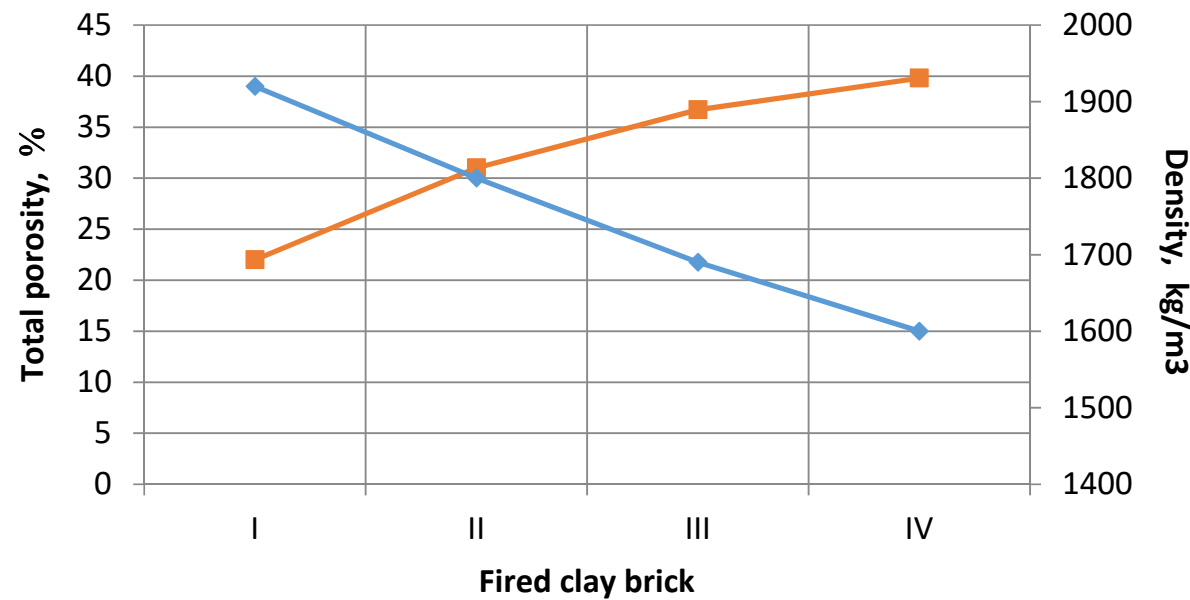

$\longrightarrow$ Total porosity, \% $\leadsto$ Density, $\mathrm{kg} / \mathrm{m3}$

Figure 3. Total porosity and density of fired clay brick

The presence of fly ash particles among plastic clay particles in the moulding compound influences the development of additional pore structure in the clay matrix. The liquid phase in the clay during the firing process is not sufficient to fill in that structure of pores and non-plastic fly ash particles between the plastic clay particles and the liquid phase prevent the clay particles from getting closer. This mechanism causes the firing shrinkage and density of specimens containing MSWI fly ash addition to reduce and the total porosity of the specimens to increase (Figure 3).

There is a linear decrease in the drying and total shrinkage as the amount of waste material in the mixture increases. The total shrinkages of the samples II, III, and IV match values of $8.5-9.4 \%$.

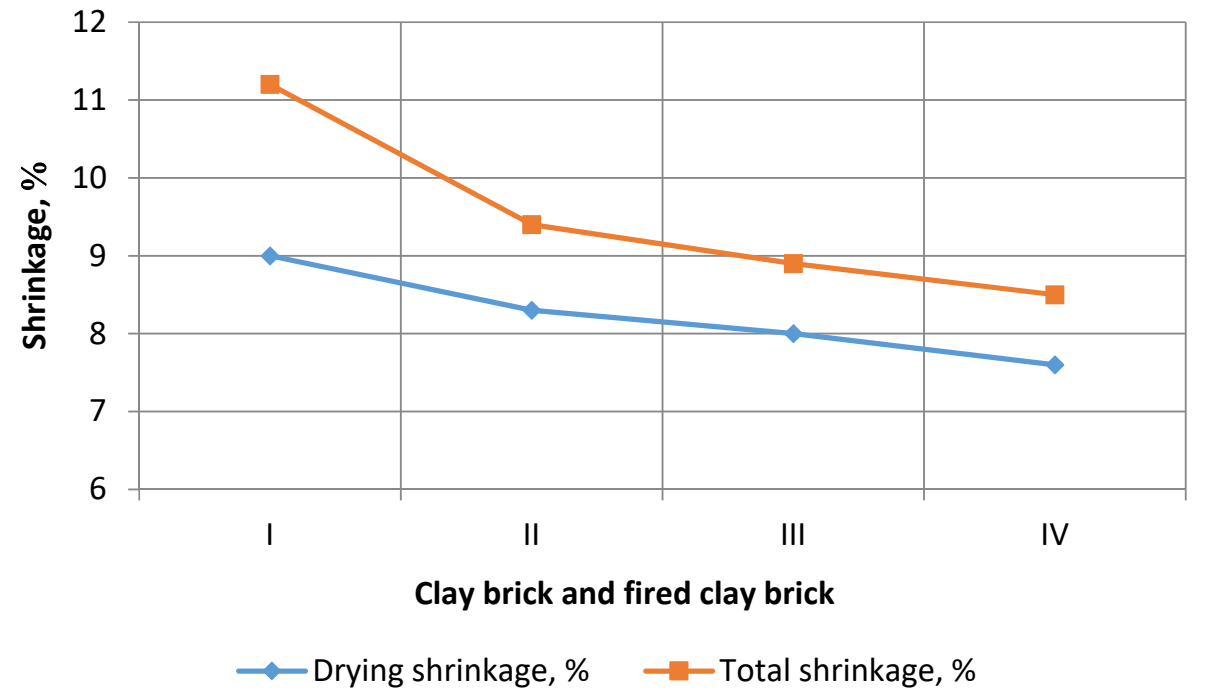

Figure 4. Total shrinkage and drying shrinkage of clay brick and fired clay brick

The compressive strength of the fired clay brick depends on the porosity content, being decreased in the fired clay bricks containing fly ash. However, the compressive strength of all fired clay bricks (I, II, III, IV samples) is higher than the standard strength of the building brick values (EN 771-1, minimum compressive strength of $8 \mathrm{MPa}$ ). Residue additions clearly decreased the compressive strength of the fired clay body compared to the control series (I samples) (Figure 5). 


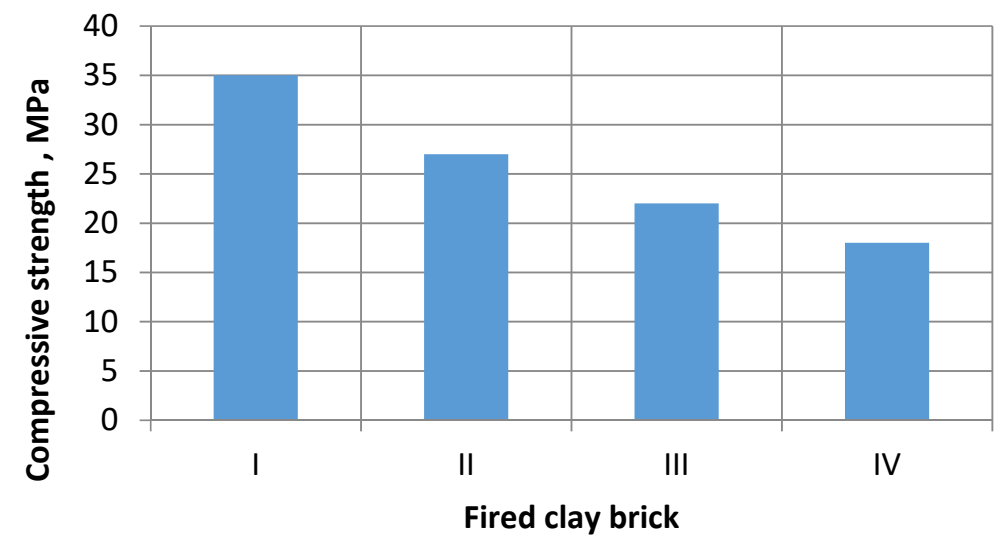

Figure 5. Compressive strength of fired clay brick

Figure 6 shows typical microstructures of clay bricks observed at the fracture surfaces after the compressive strength test. A little porous microstructure in the fired ceramic matrix (I clay brick) can be observed (Figure 6a). However, the microstructures of the clay bricks with fly ash waste addition are more porous than those of waste-free clay bricks (Figure 6b, II clay brick). These results are consistent with the values of total porosity, compressive strength and density.

The reuse of the MSWI fly ash in the fired clay brick production process may provide an economical building brick and help to protect the environment. However, the environmental toxicity (leaching of heavy metals, chlorides and sulphates) of fired clay brick must be researched. Leaching, sulphate and chloride tests indicated that, according to the EU standards, clay brick with 2.5 fly ash additions is classified as an inert material.

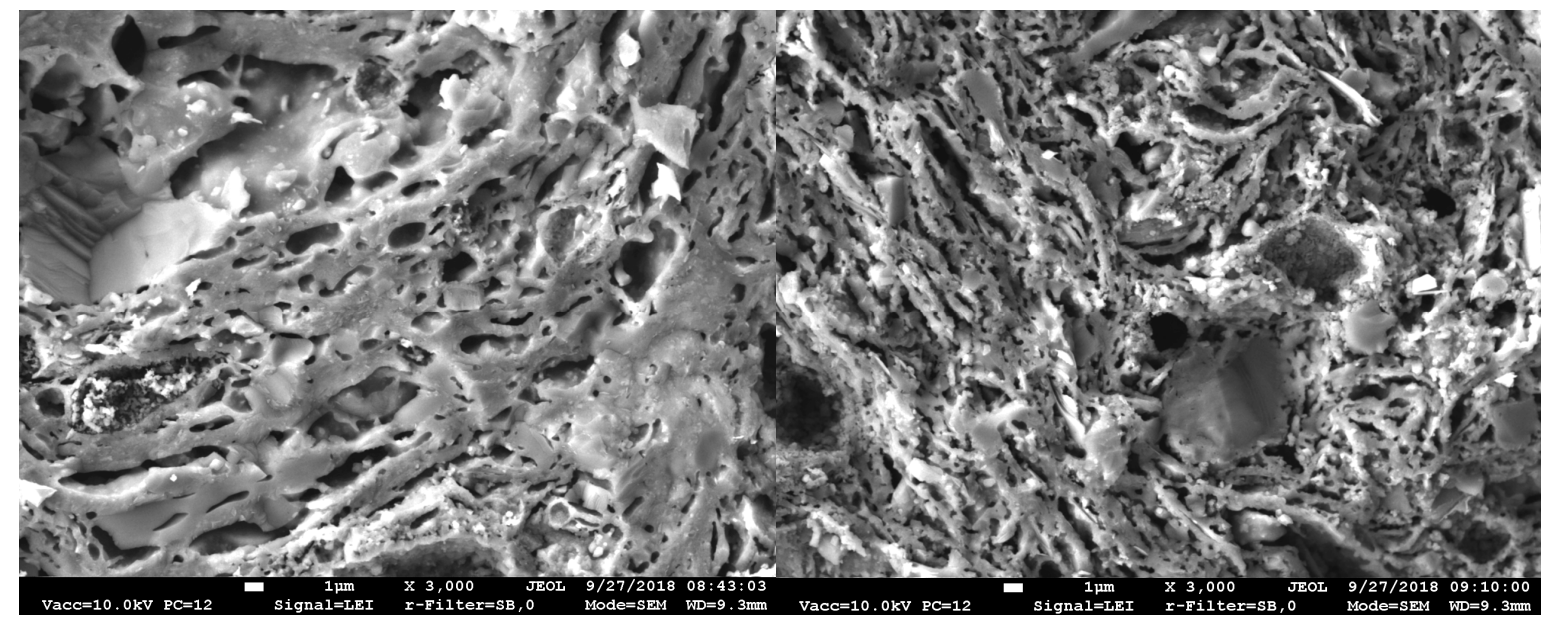

Figure 6. Microstructure of the fracture surface of the fired clay bricks: a) I fired clay brick; b) II fired clay brick

\section{Conclusions}

Based on the experimental investigations reported in this paper, the following conclusions can be drawn:

- adding fly ash residues to the unfired clay body decreases the plasticity index;

- the fly ash decreased the drying shrinkage and total shrinkage. This effect may improve the technological properties in manufacturing of a fired clay brick;

- the compressive strength of the fired clay brick is decreased by the addition of residues. Nevertheless, the values are still higher than required by standards;

- the fly ash increased the total porosity and decreased the bulk density. This effect may improve the thermal insulation properties and lower dead load in buildings;

- leaching, sulfate and chloride tests indicated that, according to EU standards, clay brick with $2.5 \%$ fly ash additions is classified as an inert material.

The recycling of MSWI fly ash waste in clay bricks shows positive results in terms of environmental protection, waste management practices, and saving of raw materials. 


\section{References}

Arsenović, M., Radojević, Z., Jakšić, Z., \& Pezo, L. (2015). Mathematical approach to application of industrial wastes in clay brick production - Part I: Testing and analysis. Ceramics International, 41(3), 4890-4898. https://doi.org/10.1016/j.ceramint.2014.12.051

Arsenovic, M., Radojevic, Z., \& Stankovic, S. (2015). Removal of toxic metals from industrial sludge by fixing in brick structure. Construction and Building Materials, 37, 7-14. https://doi.org/10.1016/j.conbuildmat.2012.07.002

Aubert, J. E., Husson, B., \& Sarramone, A. (2007). Utilization of municipal solid waste incineration (MSWI) fly ash in blended cement: Part 2. Mechanical strength of mortars and environmental impact ucts. Juornal of Hazardous Materials, 146(1-2), 12-19. https://doi.org/10.1016/j.jhazmat.2006.11.044

Aubert, J. E., Husson, B., \& Sarramone, N. (2006). Utilization of municipal solid waste incineration (MSWI) fly ash in blended cement: Part 1: Processing and characterization of MSWI fly ash. Journal of Hazardous Materials, 136(3), 624-631. https://doi.org/10.1016/j.jhazmat.2005.12.041

Belmonte, L. J., Ottosen, L. M., Kirkelund, G. M., Jensen, P. E., \& Vestbo, A. P. (2018). Screening of heavy metal containing waste types for use as raw material in Arctic clay-based bricks. Environmental Science and Pollution Research, 25(33), 32831-32843. https://doi.org/10.1007/s11356-016-8040-z

Europe Waste Catalog. (2015). Guidance on using the European Waste Catalogue (EWC) to code waste. Retrieved from https://www.sepa.org.uk/media/163421/ewc_guidance.pdf

Gao, X., Wang, W., Ye, T., Wang, F., \& Lan, Y. (2008). Utilization of washed MSWI fly ash as partial cement substitute with the addition of dithiocarbamic chelate. Journal of Environmental Management, 88(2), 293-299. https://doi.org/10.1016/j.jenvman.2007.02.008

Hwang, C. L., Bui, L. A-T., Lin, K. L., \& Lo, C. T. (2012). Manufacture and performance of lightweight aggregate from municipal solid waste incinerator fly ash and reservoir sediment for self-consolidating lightweight concrete. Cement and Concrete Composites, 34(10), 1159-1166. https://doi.org/10.1016/j.cemconcomp.2012.07.004

Jordán, M. M., Montero, M. A., Rincón-Mora, B., Rincón, J. M., \& Sanfeliu, T. (2015). Rustic ceramic covering tiles obtained by recycling of marble residues and msw fly ash. Fresenius Environmental Bulletin, 24(2), 533-538.

Kizinievič, O., Kizinievič, V., Pundienė, I., \& Molotokas, D. (2018). Eco-friendly fired clay brick manufactured with agricultural solid waste. Archives of Civil and Mechanical Engineering, 18(4), 1156-1165. https://doi.org/10.1016/j.acme.2018.03.003

Lithuanian Standards Board. (2003a). Methods of test for masonry units - Part 13: Determination of net and gross dry density of masonry units (except for natural stone) (LST EN 772-13:2003). 8 p.

Lithuanian Standards Board. (2011a). Methods of test for masonry units - Part 21: Determination of water absorption of clay and calcium silicate masonry units by cold water absorption (LST EN 771-21:2011). 10 p.

Lithuanian Standards Board. (2011b). Methods of test for masonry units - Part 1: Determination of compressive strength (LST EN 772-1:2011). 11 p.

Lithuanian Standards Board. (2003b). Characterisation of waste - Leaching - Compliance test for leaching of granular waste materials and sludges - Part 2: One stage batch test at a liquid to solid ratio of $10 \mathrm{l} / \mathrm{kg}$ for materials with particle size below $4 \mathrm{~mm}$ (without or with size reduction) (LST EN 12457-2:2003).

Mačiulaitis, R. (1996). Fasadinès keramikos atsparumas šalčiui ir ilgaamžiškumas [Frost resistance and durability of ceramic facade products]. Vilnius: Technika.

Pan, J. R., Huang, C., Kuo, J. J., \& Lin, S. H. (2008). Recycling MSWI bottom and fly ash as raw materials for Portland cement. Waste Managament, 28, 1113-1118. https://doi.org/10.1016/j.wasman.2007.04.009

Pan, Y., Wu, Z., Zhou, J., Zhao, J., Ruan, X., Liu, J., \& Qian, G. (2013). Chemical characteristics and risk assessment of typical municipal solid waste incineration (MSWI) fly ash in China. Journal of Hazardous Materials, 261, 269-276. https://doi.org/10.1016/j.jhazmat.2013.07.038

Sadūnas, A. (1999). Aliumosilikatu degimas redukuojančiu-oksiduojančiu dujų terpejje [Aluminosilicate products burning process in the reducing-oxidizing gas medium]. Vilnius: VPU leidykla.

Shi, H. S., \& Kan, L. L. (2009). Leaching behavior of heavy metals from municipal solid wastes incineration (MSWI) fly ash used in concrete. Journal of Hazardous Materials, 164(2-3), 750-754. https://doi.org/10.1016/j.jhazmat.2008.08.077

Siddique, R. (2010). Utilization of municipal solid waste (MSW) ash in cement and mortar. Resources, Conservation and Recycling, 54(12), 1037-1047. https://doi.org/10.1016/j.resconrec.2010.05.002

Tang, J., Petranikova, M., Ekberg, C., \& Steenari, B. M. (2017). Mixer-settler system for the recovery of copper and zinc from MSWI fly ash leachates: An evaluation of a hydrometallurgical process. Journal of Cleaner Production, 148, 595-605. https://doi.org/10.1016/j.jclepro.2017.02.015

Van Herck, P., Van der Bruggen, B., Vogels, G., \& Vandecasteele, C. (2000). Application of computer modelling to predict the leaching behaviour of heavy metals from MSWI fly ash and comparison with a sequential extraction method. Waste Management, 20, 203-210. https://doi.org/10.1016/S0956-053X(99)00321-9

Wan, C. (2017). Electrochemical upgrading of different ashes for use in production of bricks (PhD Thesis). Department of Civil Engineering, Technical University of Denmark.

Wunsch, P., Greilinger, C., Bieniek, D., \& Kettrup, A. (1996). Investigation of the binding of heavy metals in thermally treated residues from waste incineration. Chemosphere, 32, 2211-2218. https://doi.org/10.1016/0045-6535(96)00123-3

Ye, N., Chen, Y., Yang, Y., Liang, S., Hu, Y., Xiao, B., Huang, Q., Shi, Y., Hu J., \& Wu, X. (2016). Co-disposal of MSWI fly ash and Bayer red mud using an one-part geopolymeric system. Journal of Hazardous Materials, 318, 70-78.

https://doi.org/10.1016/j.jhazmat.2016.06.042 